\title{
OPTIMASI RASIO TEPUNG TERIGU, TEPUNG PISANG DAN TEPUNG UMBI TALAS SERTA ZAT ADITIF PADA PEMBUATAN MIE BASAH
}

\section{RATIO OPTIMIZATION OF WHEAT FLOUR, BANANA FLOUR, TARO FLOUR AND ADDITIVES SUBSTANCE IN PROCESSING OF WET NOODLE}

\author{
Wahyudi ${ }^{1)}$ \\ 1) Program Studi Teknologi Pertanian, Fakultas Pertanian, Universitas Dehasen Bengkulu \\ Email : wahyudi96@yahoo.co.id
}

\begin{abstract}
ABSTRAK
Mie biasanya terdiri dari tepung terigu, Penggunaan tepung pisang dan tepung umbi talas bertujuan untuk dapat tetap menghasilkan mie dengan struktur mikro dan cita rasa yang sama dengan mie berbasis tepung terigu, maka perlu dicari bahan untuk mensubstitusi fungsi gluten tersebut. Penelitian ini bertujuan untuk mengetahui penggaruh meggunakan CMC dan karagenan terhadap kadar air, kadar abu, elastisitas mutu organoleptik mie basah. Penelitian ini dilakukan 3 tahap, yaitu tahap pengolahan tepung pisang dan tepung umbi talas, tahap pengolahan mie basah dan tahap analisis. Penelitian ini terdiri dari 2 perlakuan dan perlakuan perbandingan tepung terigu: tepung pisang: tepung umbi talas dan perlakuan penggunaan zat aditif. Analisis yang dilakukan meliputi analisa kadar air, kadar abu, elastisitas dan uji organoleptik mie basah.

Hasil analisa kadar air, kadar abu, elastisitas mie basah menunjukkan perbedaan yang nyata pada tingkat signifikasi 5\%. Dengan nilai kadar air 48,89\% hingga 56,15\%, kadar abu 1,26\% hingga 3,07 dan elastisitas 2,54 hingga 3,45. Hasil analisa uji organoleptik menunjukkan pengaruh yang nyata terhadap warna, rasa, tekstur, dan aroma pada tingkat singnifikasi 5\%. Dengan skala nilai rasa mie basah 3,2 hingga 3,95, warna mie basah 3,35 hingga 4,25, aroma mie basah 3,45 hingga 4,05, tekstur mie basah 3,2 hingga 3,75.
\end{abstract}

Kata kunci : mie basah, tepung terigu, tepung pisang dan tepung umbi talas

\section{ABSTRACT}

Noodle usually consists of wheat flour. The use of banana flour and taro tuber flour aim to produce noodles with microstructure and similar taste to wheat flour-based noodles. It is necessary to find materials to substitute the function of the gluten. Therefore, the purpose of this study was to know the effect of using CMC and karagen on water content, ash content, wet noodle elasticity of the organoleptic quality. This research was conducted three steps, namely banana and tuber taro flour processing, wet noodle processing and analisis step. This study consisted of two treatment, such as: comparison treatment wheat flour : banana flour : taro tuber flour and additives substance treatment. The analysis was conducted such as water content, ash content, elasticity and organoleptic test of wet noodle.

Results of analysis water content, ash content, elasticity of wet noodle showed differences at 5\% significance level. In water content $48.89 \%$ to $56.15 \%$, ash content of $1.26 \%$ up to 3.07 and elasticity 2.54 to 3.45. The results of organoleptic tests showed significant effect on the color, taste, texture and flavor at 5\% significance level. In the scale 
of wet noodles taste between 3.2 and 3.95, the color 3.35 to 4.25 , the flavor 3.45 to 4.05 and the texture of wet noodles 3.2 to 3.75 .

Keywords: wet noodles, wheat flour, banana flour and taro tuber flour.

\section{PENDAHULUAN}

Diversifikasi pangan di Indonesia menjadi masalah penting bagi masyarakat maupun pemerintah (Suyastiri, 2008). Selain untuk mempertahankan ketahanan pangan di Indonesia, diversifikasi pangan berperan juga dalam meningkatkan gizi pangan dan nilai tambah dari berbagai komoditi. Mengingat kekayaan Indonesia akan komoditi - komoditi pangan, maka perlu dikembangkan produksi makanan dari sumber-sumber yang belum banyak dimanfaatkan dan nutrisinya cukup baik (Antarlina dan Utomo, 1997).

Karena alasan tekstur dan cita rasa, mie umumnya dibuat dari tepung terigu yang nilai Glycemix Index-nya tinggi (85). GI yang tinggi menaikkan kadar gula darah dengan cepat yang mendorong pada kegemukan. Dari sekian banyak sumber karbohidrat, dipilih tepung pisang dan umbi talas dengan nilai GI lebih rendah (56 dan 61) ( Chandler, 1995), yang dapat memperlambat pelepasan kadar gula darah sehingga dapat bertahan cukup lama di usus besar (resistant starch tinggi). Bahan baku ini harganya murah dan produksinya masih dapat ditingkatkan karena budidayanya mudah. Pertimbangan lain, pisang dan umbi talas memiliki kandungan nilai gizi dan serat yang baik (FAO, 1990).

Hal yang membedakan tepung terigu dengan tepung lain adalah gluten yang menentukan sifat rheologi dan tekstur adonan mie. Untuk dapat tetap menghasilkan mie dengan struktur mikro dan cita rasa yang sama dengan mie berbasis tepung terigu, maka perlu dicari bahan untuk mensubstitusi fungsi gluten tersebut (Astawan, 2008). Dengan dapat dikembangkannya tepung pisang dan umbi talas sebagai bahan baku pembuatan mie. Penggunaan CMC sebesar 1,5\% akan dapat meningkatkan kekenyalan dan keliatan, tidak lengket dan licin. CMC juga berfungsi agar mie menjadi lebih elastis dan tidak mudah menjadi bubur apabila mie dimasak ( Suyastiri, 2008). Penambahan karagenan pada mie basah dapat meningkatkan kekenyalan karena mampu berinteraksi dengan makro molekul sehingga mampu membentuk gel (FAO, 1990).

\section{METODE PENELITIAN}

\section{Bahan Penelitian}

Bahan baku pembuat adonan mie yang digunakan dalam penelitian ini, yaitu pisang, umbi talas, tepung terigu, air, 
telur, garam dan minyak goreng. Sementara, zat aditif yang digunakan dalam penelitian ini untuk menggantikan fungsi gluten adalah CMC dan karagenan.

\section{Peralatan Penelitian}

Peralatan utama dalam penelitian ini yaitu mixer, neraca, dryer, blender alat pembuat mie (ekstruder sederhana dan roller), saringan dan kompor. Untuk analisis, digunakan peralatan pendukung berupa texture analyzer, hot plate, dan moisture analyzer.

\section{Prosedur Penelitian}

Prosedur penelitian yang
dilakukan dalam pembuatan tepung pisang dan tepung umbi talas yaitu :

a. Pisang atau umbi talas yang sudah cukup matang atau tua, dan yang berkualitas baik tanpa cacat. dikupas kulitnya dan potong-potong dengan ketebalan $\pm 3 \mathrm{~mm}$

b. Kemudian direndam di dalam 2 liter air yang telah dicampurkan dengan 1,5 g sodium metabisulfit. Durasi perendaman selama 10 menit. Perendaman ini dilakukan dengan tujuan untuk menghilangkan getah.

c. Setelah 10 menit, potongan pisang ditiriskan dalam sebuah wadah yang berpori. d. Setelah bersih dari larutan rendaman, dijemur di bawah terik sinar matahari. Penjemuran kurang lebih 2 hari.

e. Setelah kering sempurna, bahan kemudian digiling atau dihaluskan dengan menggunakan blender.

f. Proses pengayakan menggunakan 80 mesh jadilah tepung

\section{Proses Pengolahan Mie Basah}

Pengolahan mie basah dengan variasi perlakuan bahan baku yaitu komposisi tepung terigu, tepung pisang dan tepung umbi talas serta penambahan CMC dan karagenan. Proses pengolahan mie basah sebagai berikut :

a. Tepung terigu dicampur dengan tepung pisang dan tepung umbi talas dengan komposisi sesuai perlakuan. Kemudian ditambah garam 10 g, telur 1 butir air $200 \mathrm{ml}$ dan $1,5 \%$ zat aditif (CMC atau Karagenan) hingga membentuk adonan yang kalis.

b. Pembentukan lembaran mie, menggunakan roll press. Kemudian dilakukan pembaluran dengan tepung terigu sebanyak $50 \mathrm{~g}$ dengan tujuan agar mie yang dihasilkan dapat terpisah satu sama lainnya

c. Pencetakan mie, dengan menggunakan alat cetak mie

d. Perebusan, dilakukan selama 3 menit dalam air panas dengan suhu $90^{\circ} \mathrm{C}$ 
e. Penirisan dan pembaluran, setelah proses perebusan kemudian dilakukan penirisan dan pembaluran dengan minyak goreng $30 \mathrm{ml}$.

\section{Perlakuan Penelitian}

Penelitian ini terdiri dari 2 perlakuan yaitu perlakuan komposisi tepung dan penambahan zat aditif dengan uraian berikut :

A. Variasi perlakuan komposisi tepung :

T1 : Terigu, pisang dan umbi talas ( $100 \mathrm{~g}, 200 \mathrm{~g}, 300 \mathrm{~g}$ )

T2 : Terigu, pisang dan umbi talas ( $200 \mathrm{~g}, 300 \mathrm{~g}, 100 \mathrm{~g}$ )

T3 : Terigu, pisang dan umbi talas ( $300 \mathrm{~g}, 100 \mathrm{~g}, 200 \mathrm{~g}$ )

B. Variasi perlakuan penambahan zat aditif :

\section{P1 : $\mathrm{CMC} 1,5 \%$ \\ P2 : Karagenan 1,5\%}

\section{Analisis Penelitian}

Analisis penelitian yaitu dengan menganalisis kadar air, kadar abu dan elastisitas mie basah yang dihasilkan serta dilakukan uji organoleptik dengan parameter warna, rasa, tekstur, dan aroma dengan 20 panelis terlatih.

\section{HASIL DAN PEMBAHASAN}

\section{Hasil Analisis Rendemen}

$\begin{array}{rrr} & \text { Rendemen adalah peresentase } \\ \text { produk yang didapatkan dari }\end{array}$ membandingkan berat awal bahan dengan berat akhirnya. Sehingga dapat diketahui kehilangan beratnya proses pengolahan. Rendeman didapatkan dengan cara (menghitung) menimbang berat akhir bahan yang dihasilkan dari proses dibandingkan dengan berat bahan awal sebelum mengalami proses. (Mushollaeni, 2006)

\section{Rendemen Tepung Pisang}

Pengolahan tepung pisang dilakukan menggunakan 3000 g Pisang Ambon mengkal melalui proses pengirisan, penjemuran dan pengayakan sehingga dihasilkan tepung pisang sebanyak 1000 g. Sehingga diperoleh rendemen sebagai berikut:

$$
\text { Rendemen }=\frac{1000}{3000} \times 100 \%=33,33 \%
$$

Dari hasil perhitungan rendemen pengolahan tepung pisang di atas bisa diketahui bahwa pengolahan tepung pisang menghasilkan rendemen sebesar $33,33 \%$.

\section{Rendemen Tepung Umbi Talas}

Pengolahan tepung umbi talas dilakukan menggunakan 3000 g umbi talas melalui proses pengirisan, penjemuran dan pengayakan sehingga dihasilkan tepung umbi talas sebanyak 1000 g. Sehingga diperoleh rendemen sebagai berikut: 
Rendemen $=\frac{1000}{3000} \times 100 \%=33,33 \%$

Dari hasil perhitungan rendemen pengolahan tepung umbi talas di atas bisa diketahui bahwa pengolahan tepung umbi talas menghasilkan rendemen sebesar $33,33 \%$.

\section{Rendemen Pengolahan Mie Basah}

Pengolahan mie basah menggunakan tepung terigu, tepung pisang dan tepung umbi talas digunakan $600 \mathrm{~g}$, sehingga dihasilkan mie basah sebanyak 1000 g. Sehingga diperoleh rendemen sebagai berikut:

Rendemen $=\frac{1000}{600} \times 100 \%=166,66 \%$

Dari hasil perhitungan rendemen pengolahan mie basah di atas bisa diketahui bahwa pengolahan mie basah menghasilkan rendemen sebesar 166,66 $\%$.

\section{Hasil Analisis Kadar Air Mie Basah}

Air merupakan komponen penting dalam bahan makanan, karena dapat mempengaruhi penampakan, tekstur, serta cita rasa makanan. Kandungan air dalam makanan itu menentukan acceptability, kesegaran daya tahan bahan (Winarno, 2004). Walaupun air bukan merupakan sumber nutrien, tetapi sangat esensial dalam proses biokimiawi organisme hidup. Oleh karena itu, kadar air dalam bahan pangan sangat menentukan sifat fisik, kimia, organoleptik dan umur simpan bahan pangan yang bersangkutan. Hasil analisis kadar air mie basah dengan perlakuan komposisi tepung terigu, tepung pisang, dan tepung umbi talas dapat dilihat pada tabel 1 .

Tabel 1. menjelaskan hasil rerata analisis terhadap mie basah dengan perlakuan perbandingan tepung terigu, pisang dan umbi talas serta penambahan CMC dan karagenan menunjukkan perbedaan nyata pada taraf signifikan $5 \%$. Rerata analisis kadar air mie basah dengan perlakuan komposisi tepung terigu : pisang : umbi talas (100 g : $200 \mathrm{~g}: 300 \mathrm{~g}$ ) dengan CMC (1,5\%) yaitu 51,11\% dan karagenan $(1,5 \%)$ yaitu $56,15 \%$ perlakuan dengan komposisi tepung terigu : pisang : umbi talas (200: $300: 100)$ dengan CMC $(1,5 \%)$ yaitu $53,30 \%$ dan karagenan $(1,5 \%)$ yaitu $51,46 \%$,dan perlakuan dengan komposisi tepung terigu : pisang : umbi talas (300 g : $100 \mathrm{~g}: 200 \mathrm{~g}$ ) dengan CMC (1,5\%) yaitu $54,31 \%$ dan karagenan $(1,5 \%)$ yaitu 48,89. Kadar air pada mie basah dengan perlakuan komposisi tepung terigu, tepung pisang dan tepung umbi talas belum sesuai standar SNI (1992) yaitu kandungan kadar air mie basah berkisar antara 20\% hingga $35 \%$. Pada penelitian ini kadar air mie basah tidak memenuhi standar SNI. 
Tabel 1 Nilai Rerata Analisis Kadar Air Mie Basah (\%)

\begin{tabular}{|l|l|l|l|}
\hline \multirow{2}{*}{ Zat Aditif } & \multicolumn{3}{|l|}{ Komposisi Tepung (Terigu : Pisang : Umbi Talas) } \\
\cline { 2 - 4 } & $100 \mathrm{~g}: 200 \mathrm{~g}: 300 \mathrm{~g}$ & $200 \mathrm{~g}: 300 \mathrm{~g}: 100 \mathrm{~g}$ & $300 \mathrm{~g}: 100 \mathrm{~g}: 200 \mathrm{~g}$ \\
\hline CMC (1,5\%) & $51,11^{\mathrm{b}}$ & $53,30^{\mathrm{b}}$ & $54,31^{\mathrm{a}}$ \\
\hline Karagenan $(1,5 \%)$ & $56,15^{\mathrm{a}}$ & $51,46^{\mathrm{b}}$ & $48,89^{\mathrm{b}}$ \\
\hline
\end{tabular}

Ket : angka yang diikuti oleh kode huruf yang berbeda menunjukkan adanya perbedaan yang nyata pada tarif signifikasi $5 \%$.

\section{Hasil Analisis Kadar Abu Mie Basah}

Kadar abu merupakan campuran dari komponen anorganik atau mineral yang terdapat pada suatu bahan pangan. Bahan pangan terdiri dari $96 \%$ bahan anorganik dan air, sedangkan sisanya merupakan unsur - unsur mineral. Unsur juga dikenal sebagai zat organik atau kadar abu. Kadar abu tersebut dapat menunjukkan total mineral dalam suatu bahan pangan. Bahan - bahan organik dalam proses pembakaran akan terbakar tetapi komponen anorganiknya tidak, karena itulah disebut sebagai kadar abu (Zahro, 2013). Penentuan kadar abu total bertujuan untuk menentukan baik atau tidaknya suatu pengolahan, mengetahui jenis bahan yang digunakan, dan sebagai penentu parameter nilai gizi suatu bahan makanan. Abu adalah zat anorganik sisa hasil pembakaran suatu bahan organik. penentuan kadar abu berhubungan erat dengan kandungan mineral yang terdapat dalam suatu bahan, kemurnian serta kebersihan suatu bahan yang dihasilkan (Zahro, 2013). Hasil analisa terhadap kadar abu mie basah dengan subtitusi tepung terigu, tepung pisang dan tepung umbi talas dengan perlakuan CMC dan karagenan dapat dilihat pada tabel 2 .

Tabel 2. Nilai Rerata Analisis Kadar Abu Mie Basah (\%)

\begin{tabular}{|l|c|c|c|}
\hline \multirow{2}{*}{ Zat Aditif } & \multicolumn{3}{|l|}{ Komposisi Tepung (Terigu : Pisang : Umbi Talas) } \\
\cline { 2 - 4 } & $100 \mathrm{~g}: 200 \mathrm{~g}: 300 \mathrm{~g}$ & $200 \mathrm{~g}: 300 \mathrm{~g}: 100 \mathrm{~g}$ & $300 \mathrm{~g}: 100 \mathrm{~g}: 200 \mathrm{~g}$ \\
\hline CMC $(1,5 \%)$ & $1,73^{\mathrm{a}}$ & $3,07^{\mathrm{a}}$ & $2,02^{\mathrm{a}}$ \\
\hline Karagenan $(1,5 \%)$ & $1,59^{\mathrm{a}}$ & $2,01^{\mathrm{a}}$ & $1,26^{\mathrm{a}}$ \\
\hline
\end{tabular}

Ket : angka yang diikuti oleh kode huruf yang berbeda menunjukkan adanya perbedaan yang nyata pada tarif signifikasi $5 \%$. 
Tabel 2. menjelaskan hasil rerata analisis kadar abu mie basah dengan perlakuan perbandingan tepung terigu, pisang dan umbi talas serta penambahan CMC dan karagenan menunjukkan tidak ada perbedaan yang nyata pada taraf signifikan 5\%. Rerata analisis kadar abu mie basah dengan perlakuan komposisi tepung terigu : pisang : umbi talas $(100 \mathrm{~g}$ : $200 \mathrm{~g}: 300 \mathrm{~g})$ dengan CMC (1,5\%) yaitu $1,73 \%$ dan karagenan $(1,5 \%)$ yaitu $1,59 \%$, perlakuan dengan komposisi tepung terigu : pisang : umbi talas (200 : $300: 100)$ dengan CMC (1,5\%) yaitu $3,07 \%$ dan karagenan $(1,5 \%)$ yaitu $2,01 \%$, dan perlakuan dengan komposisi tepung terigu : pisang : umbi talas (300 g : $100 \mathrm{~g}: 200$ g) dengan CMC (1,5\%) yaitu 2,02\% dan karagenan $(1,5 \%)$ yaitu $1,26 \%$.

Hasil analisis kadar abu mie basah dengan perlakuan komposisi tepung terigu, tepung pisang, dan tepung umbi talas sesuai dengan standar SNI (1992) dimana kandungan kadar abu maksimum yaitu 3\%, sedangkan pada perlakuan komposisi tepung terigu, tepung pisang dan tepung umbi talas kandungan kadar abu berkisar antara 1,26\% hingga 3,07\%. Kadar abu adalah zat anorganik hasil pembakaran suatu bahan organik dimana kadar abu tersebut berhubungan dengan mineral suatu bahan yang dipengaruhi oleh varitas dan bagian tanaman yang digunakan (Sudarmadji et al.,1989).
Zat aditif adalah zat yang ditambahkan ke dalam makanan sebagai hasil dari berbagai tahap pengolahan, penyimpanan, maupun pengemasan. Zat aditif berperan sebagai bentuk modifikasi bahan-bahan yang secara alamiah ada dalam bahan makanan sebelumnya. Penambahan zat aditif berupa CMC dan karagenan tidak berpengaruh terhadap kadar abu mie basah.

\section{Hasil Analisis Elastisitas Mie Basah}

Elastisitas mie basah dalam penelitian ini diketahui melalui akumulasi waktu yang dibutuhkan oleh mie untuk menahan beban $0,58 \mathrm{~g}$ yang diberikan sampai mie tersebut putus, semakin lama waktu yang dibutuhkan mie untuk menahan beban sampai mie tersebut putus maka semakin elastis mie yang dihasilkan. Hasil analisis waktu putus mie basah dengan subtitusi tepung terigu, tepung pisang dan tepung umbi talas dengan perlakuan $\mathrm{CMC}$ dan karagenan dapat dilihat pada tabel 3 .

Tabel 3. menjelaskan hasil rerata analisis elastisitas mie basah dengan perlakuan perbandingan tepung terigu, pisang dan umbi talas serta penambahan CMC dan karagenan menunjukkan tidak beda nyata pada taraf signifikan 5\%. Rerata analisis elastisitas mie basah dengan perlakuan komposisi tepung terigu : pisang : umbi talas (100 g : $200 \mathrm{~g}$ : 
300 g) dengan CMC 1,5\% yaitu 2,85 dan karagenan $(1,5 \%)$ yaitu 2,54 , perlakuan dengan komposisi tepung terigu : pisang : umbi talas (200: $300: 100)$ dengan CMC $(1,5 \%)$ yaitu 3,25 dan karagenan $(1,5 \%)$ yaitu 2,95, dan perlakuan dengan komposisi tepung terigu : pisang : umbi talas (300 g : $100 \mathrm{~g}: 200 \mathrm{~g}$ ) dengan CMC $(1,5 \%)$ yaitu 3,45 dan karagenan $(1,5 \%)$ yaitu 3,12 .

Dari hasil penelitian Jaka (2015) yang berjudul "Subtitusi Umbi Gadung pada Penggolahan Mie Basah" kekenyalan mie basah dapat diketahui melalui akumulasi waktu yang dibutuhkan mie untuk terputus, semakin lama waktu yang dibutuhkan oleh mie untuk menahan beban $0,58 \mathrm{~g}$ yang diberikan sampai mie tersebut putus maka semakin elastis mie yang dihasilkan. Hasil analisa terhadap waktu putus mie dengan subtitusi tepung gadung perlakuan garam dan perlakuan abu dan dapat dilihat perbedaan yang tidak nyata terhadap analisa elastisitas setiap subtitusi tepung gadung perlakuan garam dan perlakuan abu pada pengolahan mie basah pada taraf 5\%. Subtitusi tepung gadung perlakuan garam 400 gr : 300 gr: 200 gr, menunjukkan waktu putus 3,45 detik, 3,25 detik, 2,85 detik, dan tepung gadung perlakuan g semakin tinggi tepung gadung semakin elastis. Penelitian tersebut senada dengan hasil penelitian ini menunjukan nilai elastisitas mie berkisar antara 2,54 sampai 3,45 .

$$
\text { Tepung terigu banyak }
$$
mengandung gluten atau protein terigu. gluten terdiri dari protein gliadin dan glutenin. Gliadin berfungsi sebagai perekat dan menjadikan adonan lebis elastis sedangkan glutenin berfungsi menjadikan adonan tetap kokoh dan menahan gas $\mathrm{CO}_{2}$ sehingga adonan dapat mengembang serta berbentuk pori-pori (Anonim,2008), nilai elastisitas mie basah dengan subtitusi tepung gadung dalam penelitian ini bekisar antara 2,54 sampai 3,45 detik.

Tabel 3. Nilai Rerata Analisis Elastisitas Mie Basah (Detik)

\begin{tabular}{|l|l|l|l|}
\hline \multirow{2}{*}{ Zat Aditif } & \multicolumn{3}{|l|}{ Komposisi Tepung (Terigu : Pisang : Umbi Talas) } \\
\cline { 2 - 4 } & $100 \mathrm{~g}: 200 \mathrm{~g}: 300 \mathrm{~g}$ & $200 \mathrm{~g}: 300 \mathrm{~g}: 100 \mathrm{~g}$ & $300 \mathrm{~g}: 100 \mathrm{~g}: 200 \mathrm{~g}$ \\
\hline CMC $(1,5 \%)$ & $2,85^{\mathrm{a}}$ & $3,25^{\mathrm{a}}$ & $3,45^{\mathrm{a}}$ \\
\hline Karagenan $(1,5 \%)$ & $2,54^{\mathrm{a}}$ & $2,95^{\mathrm{a}}$ & $3,12^{\mathrm{a}}$ \\
\hline
\end{tabular}

Ket : angka yang diikuti oleh kode huruf yang berbeda menunjukkan adanya perbedaan yang nyata pada tarif signifikasi $5 \%$. 
Hal ini senada hasil penelitian Siti Permatasari dkk tahun ( 2009), menyatakan elastisitas mie basah dengan perlakuan tupung talas. Hal ini didukung oleh pendapat Anonim (2006) yang menyatakan bahwa subtitusi atau campuran tepung lain pada produk mie yang semakin tinggi menyebabkan produk mie akan mudah putus karena kandungan gluten menurun. Tepung terigu banyak mengandung gluten atau protein terigu.

Gluten terdiri dari protein gliadin dan glutenin. Gliadin berfungsi sebagai perekat dan menjadikan adonan lebih elastis sedangkan glutenin berfungsi menjadikan adonan tetap kokoh dan menahan gas $\mathrm{CO}_{2}$ sehingga adonan dapat mengembang serta terbentuk pori-pori (Anonim, 2008).

Pengaruh rasio tepung yang digunakan juga berhubungan dengan ukuran granula pati. Ukuran granula pati gandum berukuran 2-35 $\mu \mathrm{m}$, granula pati umbi jalar berukuran 16- $25 \mu \mathrm{m}$, sedangkan granula pati pisang berukuran 35-55 $\mu \mathrm{m}$ (Knight, 1969). Dapat dilihat bahwa ukuran granula terbesar terdapat pada pati pisang. Hal ini menyebabkan pati pisang dapat menyerap air lebih banyak, sehingga memberikan tingkat kekerasan mie yang lebih rapuh. Oleh karena itu, komposisi tepung yang mengandung campuran tepung pisang dan tepung umbi talas yang lebih banyak, menyebabkan tingkat elastisitas mie semakin rapuh. Berkurangnya jumlah tepung terigu yang digunakan mengakibatkan terjadinya penurunan elastisitas mie basah. Zat aditif yang ditambahkan berada pada rentang yang relatif kecil (1\%-2\%) sehingga perubahannya pada tingkat kekerasan mie tidak terlalu terlihat.

\section{Organoleptik Warna Mie Basah}

Warna merupakan parameter organoleptik yang penting dalam suatu produk makanan. Warna merupakan parameter pertama yang menentukan tingkat penerimaan konsumen terhadap suatu produk. Hasil rerata uji organoleptik warna mie basah dengan subtitusi tepung terigu, tepung pisang dan tepung umbi talas dengan perlakuan CMC dan karagenan dapat dilihat pada tabel 4 .

Tabel 4. menjelaskan hasil rerata uji organoleptik warna terhadap mie basah dengan perlakuan perbandingan tepung terigu, pisang dan umbi talas serta penambahan CMC dan karagenan menunjukkan perbedaan nyata pada taraf signifikan 5\%. Rerata uji organoleptik warna mie basah dengan perlakuan komposisi tepung terigu : pisang : umbi talas (100 g : $200 \mathrm{~g}: 300 \mathrm{~g})$ dengan CMC (1,5\%) yaitu 3,75 (suka) dan karagenan $(1,5 \%) \quad 4,1$ (suka), perlakuan dengan komposisi tepung terigu : pisang : umbi 
talas (200: $300: 100)$ dengan CMC (1,5\%) yaitu 4,25 (suka) dan karagenan $(1,5 \%)$ yaitu 3,35 (agak suka), dan perlakuan dengan komposisi tepung terigu : pisang : umbi talas (300 g : $100 \mathrm{~g}: 200$ g) dengan $\mathrm{CMC}(1,5 \%)$ yaitu 3,5 (agak suka) dan karagenan (1,5\%) yaitu 3,6 (suka).

Hasil uji organoleptik terhadap warna mie basah dengan perlakuan komposisi tepung terigu, tepung pisang dan tepung talas serta penambahan CMC 1,5\% dan karagenan $1,5 \%$ berkisar antara 3,35 (agak suka) hingga 4,25 (suka).

Perlakuan komposisi tepung terigu, tepung pisang dan umbi talas (200 $\mathrm{g}: 300 \mathrm{~g}: 100 \mathrm{~g})$ dengan CMC ( $1,5 \%)$ menunjukkan penilaian tertinggi yaitu 4,25 berada pada skala suka, warna mie basah lebih di sukai karena penambahan tepung talas dengan jumlah sedikit yaitu 100 gr pada perlakuan menyebabkan warna mie sedikit kekuningan karena komposisi tepung terigu dan tepung pisang lebih tinggi yaitu $200 \mathrm{~g}$ dan $300 \mathrm{~g}$ ). Warna tepung talas yag dihasilkan berwarna kecoklatan sehingga dapat mempengaruhi warna mie basah yang dihasilkan.

\section{Organoleptik Rasa Mie Basah}

Uji organoleptik merupakan salah satu cara penilaian terhadap suatu produk makanan yang dilakukan oleh manusia sebagai pengukuran dengan menggunakan panca-inderanya. Cita rasa merupakan suatu kesan yang diterima melalui saraf indera pengecapan, yaitu lidah. Sebagai hasil hadirnya senyawa-senyawa yang larut dalam air (Zahro, 2013). Hasil rerata uji organoleptik rasa mie basah dengan subtitusi tepung terigu, tepung pisang dan tepung umbi talas dengan perlakuan CMC dan karagenan dapat dilihat pada tabel 5.

Tabel 4. Nilai Rerata Uji Organoleptik Warna Mie Basah

\begin{tabular}{|l|l|l|l|}
\hline \multirow{2}{*}{ Zat Aditif } & \multicolumn{3}{|l|}{ Komposisi Tepung (Terigu : Pisang : Umbi Talas) } \\
\cline { 2 - 4 } & $100 \mathrm{~g}: 200 \mathrm{~g}: 300 \mathrm{~g}$ & $200 \mathrm{~g}: 300 \mathrm{~g}: 100 \mathrm{~g}$ & $300 \mathrm{~g}: 100 \mathrm{~g}: 200 \mathrm{~g}$ \\
\hline CMC $(1,5 \%)$ & $3,7^{\mathrm{a}}$ & $4,25^{\mathrm{a}}$ & $3,5^{\mathrm{b}}$ \\
\hline Karagenan $(1,5 \%)$ & $4,1^{\mathrm{a}}$ & $3,35^{\mathrm{b}}$ & $3,6^{\mathrm{b}}$ \\
\hline
\end{tabular}

Ket : Angka yang diikuti oleh kode huruf yang berbeda menunjukkan adanya perbedaan yang nyata pada taraf signifikansi $5 \%$. Ket Skala : 1= sangat tidak suka; 2 = tidak suka; 3 = agak suka; $4=$ suka; $5=$ sangat suka 
Tabel 5. Nilai Rerata Uji Organoleptik Rasa Mie Basah

\begin{tabular}{|l|l|l|l|}
\hline \multirow{2}{*}{ Zat Aditif } & \multicolumn{3}{|l|}{ Komposisi Tepung (Terigu : Pisang : Umbi Talas) } \\
\cline { 2 - 4 } & $100 \mathrm{~g}: 200 \mathrm{~g}: 300 \mathrm{~g}$ & $200 \mathrm{~g}: 300 \mathrm{~g}: 100 \mathrm{~g}$ & $300 \mathrm{~g}: 100 \mathrm{~g}: 200 \mathrm{~g}$ \\
\hline CMC $(1,5 \%)$ & $3,2^{\mathrm{b}}$ & $3,7^{\mathrm{b}}$ & $3,8^{\mathrm{a}}$ \\
\hline Karagenan $(1,5 \%)$ & $3,95^{\mathrm{a}}$ & $3,55^{\mathrm{b}}$ & $3,5^{\mathrm{b}}$ \\
\hline
\end{tabular}

Ket : Angka yang diikuti oleh kode huruf yang berbeda menunjukkan adanya perbedaan yang nyata pada taraf signifikansi $5 \%$. Ket Skala : $1=$ sangat tidak suka; 2 $=$ tidak suka; 3 = agak suka; $4=$ suka; $5=$ sangat suka

Tabel 5. menjelaskan hasil rerata uji organoleptik rasa terhadap mie basah dengan perlakuan perbandingan tepung terigu $100 \mathrm{~g}$, pisang $200 \mathrm{~g}$ dan umbi talas $300 \mathrm{~g}$ serta penambahan CMC 1,5\% menunjukkan perbedaan nyata terhadap perlakuan perbandingan konsetrasi tepung terigu, tepung pisang dan tepung umbi talas serta penambahan $\mathrm{CMC}$ dan karagenan 1,5\% pada taraf signifikan 5\%. Rerata uji organoleptik rasa mie basah dengan perlakuan komposisi tepung terigu : pisang : umbi talas (100 g : $200 \mathrm{~g}: 300$ g) dengan CMC (1,5\%) yaitu 3,2 (agak suka) dan karagenan (1,5\%) yaitu 3,95 (suka), perlakuan dengan komposisi tepung terigu : pisang : umbi talas (200 : 300 : 100) dengan CMC (1,5\%) yaitu 3,7 (suka) dan karagenan (1,5\%) yaitu 3,55 (suka), dan perlakuan dengan komposisi tepung terigu : pisang : umbi talas (300 g : $100 \mathrm{~g}: 200 \mathrm{~g})$ dengan CMC (1,5\%) yaitu 3,8 (suka) dan karagenan (1,5\%) yaitu 3,5 (agak suka).
Hasil uji organoleptik terhadap rasa mie basah dengan komposisi tepung terigu, tepung pisang dan tepung umbi talas serta penambahan CMC dan karagenan berkisar antara 3,2 hingga 3,95 berada pada skala agak suka dan suka. Rasa mie basah yang dihasilkan dengan penambahan tepung lain seperti tepung pisang dan tepung talas menunjukkan rasa yang sedikit berbeda dari pembuatan mie pada umumnya dengan menggunakan bahan baku tepung terigu sehingga rasa mie masih terasa asing oleh panelis yang menunjukkan penilaian pada rasa berada pada skala agak suka. Rasa, aroma, warna serta penampilan makanan akan mempengaruhi tingkat kesukaan masyarakat terhadap makanan (Winarno dan Rahayu, 1994)

\section{Organoleptik Aroma Mie Basah}

Winarno (1997) menyatakan bahwa diterima atau tidaknya makanan ditentukan oleh aromanya, dalam industri pangan uji aroma sangat penting karna 
dapat menentukan hasil penilaian konsumen terhadap produk yang dihasilkan. Aroma juga dapat menjadi penentu kerusakan pada produk yang akan dihasilkan. Hasil rerata uji organoleptik aroma mie basah dengan subtitusi tepung terigu, tepung pisang dan tepung umbi talas dengan perlakuan $\mathrm{cmc}$ dan karagenan dapat dilihat pada tabel 6 .

Tabel 6. menjelaskan hasil rerata uji organoletik aroma terhadap mie basah dengan perlakuan perbandingan tepung terigu, pisang dan umbi talas serta penambahan $\mathrm{CMC}$ dan karagenan menunjukkan tidak beda nyata pada taraf signifikan 5\%. Rerata uji organoleptik aroma mie basah dengan perlakuan komposisi tepung terigu : pisang : umbi talas (100 g : $200 \mathrm{~g}: 300 \mathrm{~g}$ ) dengan CMC $(1,5 \%)$ yaitu 3,45 (agak suka) dan karagenan (1,5\%) yaitu 3,46 (agak suka), perlakuan dengan komposisi tepung terigu : pisang : umbi talas (200 : 300 : 100) dengan CMC (1,5\%) yaitu 4,05 (suka) dan karagenan $(1,5 \%)$ yaitu 3,8 (suka), dan perlakuan dengan komposisi tepung terigu : pisang : umbi talas (300 g : $100 \mathrm{~g}: 200$ g) dengan CMC (1,5\%) yaitu 3,5 (agak suka) dan karagenan (1,5\%) yaitu 3,55 (suka). Hasil uji organoleptik aroma mie basah dengan perlakuan komposisi tepung terigu, tepung pisang dan tepung ubi talas serta penambahan CMC $1,5 \%$ dan karagenan $1,5 \%$ berkisar antara 3,45 berada pada skala agak suka hingga 4,05 berada pada skala suka. Karena pisang memiliki aroma yang has dan sanggat di sukai aromanya.

Penilain terhadap aroma mie basah dengan komposisi tepung terigu, tepung pisang dan tepung umbi talas (200 g : 300 $\mathrm{g}: 100 \mathrm{~g}$ ) menunjukkan penilaian yang tinggi yaitu 4,05 (suka). Penambahan zat aditif berupa CMC dan karagenan dengan konsentrasi rendah yaitu $1,5 \%$ tidak mempengaruhi aroma mie basah. Karena CMC dan karagenan adalah zat penambah jadi tidak mempenggaruhi aroma pada mie basah.

Tabel 6. Nilai Rerata Uji Organoleptik Aroma Mie Basah

\begin{tabular}{|l|l|l|l|}
\hline \multirow{2}{*}{ Zat Aditif } & \multicolumn{3}{|l|}{ Komposisi Tepung (Terigu : Pisang : Umbi Talas) } \\
\cline { 2 - 4 } & $100 \mathrm{~g}: 200 \mathrm{~g}: 300 \mathrm{~g}$ & $200 \mathrm{~g}: 300 \mathrm{~g}: 100 \mathrm{~g}$ & $300 \mathrm{~g}: 100 \mathrm{~g}: 200 \mathrm{~g}$ \\
\hline CMC $(1,5 \%)$ & $3,45^{\mathrm{b}}$ & $4,05^{\mathrm{a}}$ & $3,5^{\mathrm{b}}$ \\
\hline Karagenan $(1,5 \%)$ & $3,4^{\mathrm{b}}$ & $3,8^{\mathrm{b}}$ & $3,55^{\mathrm{b}}$ \\
\hline
\end{tabular}

Ket : Angka yang diikuti oleh kode huruf yang berbeda menunjukkan adanya perbedaan yang nyata pada taraf signifikansi $5 \%$. Ket Skala : $1=$ sangat tidak suka; 2 = tidak suka; 3 = agak suka; $4=$ suka; $5=$ sangat suka 


\section{Organoleptik Tekstur Mie Basah}

Hasil rerata uji organoleptik tekstur mie basah dengan subtitusi tepung terigu, tepung pisang dan tepung umbi talas dengan perlakuan $\mathrm{cmc}$ dan karagenan dapat dilihat pada tabel 7.

Tabel 7. menjelaskan hasil rerata analisis terhadap mie basah dengan perlakuan perbandingan tepung terigu, pisang dan umbi talas serta penambahan CMC dan karagenan menunjukkan tidak beda nyata pada taraf signifikan 5\%. Rerata analisis tekstur mie basah dengan perlakuan komposisi tepung terigu : pisang : umbi talas (100 g : $200 \mathrm{~g}: 300 \mathrm{~g}$ ) dengan CMC (1,5\%) yaitu 3,4 (agak suka) dan karagenan (1,5\%) yaitu 3,65 (suka), perlakuan dengan komposisi tepung terigu : pisang : umbi talas (200 : 300 : 100) dengan CMC (1,5\%) yaitu 3,75 (suka) dan karagenan (1,5\%) yaitu 3,2 (agak suka), dan perlakuan dengan komposisi tepung terigu : pisang : umbi talas (300 g : $100 \mathrm{~g}$ : 200 g) dengan CMC (1,5\%) yaitu 3,7 (suka) dan karagenan (1,5\%) 3,28 (agak suka).

Hasil uji organoleptik terhadap tekstur mie basah degan perlakuan komposisi tepung terigu, tepung pisang dan tepung umbi talas serta penambahan CMC $1,5 \%$ dan karagenan $1,5 \%$ berkisar antara 3,2 berada pada skala agak suka hingga 3,75 berada pada skala suka. Tekstur mie basah dapat dipengaruhi oleh penambahan tepung lain selain tepung terigu yaitu penambahan tepung pisang dan tepung umbi talas. Tan (2009) yang menyatakan bahwa subtitusi atau campuran tepung lain pada prodak mie yang semakin tinggi menyebabkan produk mie akan mudah putus karena kandungan gluten menurun. Hasil uji organoleptik terhadap mie basah yang menunujukan tidak ada perbedaan yang nyata pada mie basah dengan perlakuan jenis tepung dan jenis zat aditif yaitu CMC dan karagenan, sesuai dengan hasil analisis elastisitas mie basah berkisar antara 2,85 hingga 3,45 yang menunjukkan tidak beda nyata.

\section{Tabel 7. Nilai Rerata Uji Organoleptik Tekstur Mie Basah}

\begin{tabular}{|l|l|l|l|}
\hline \multirow{2}{*}{ Zat Aditif } & \multicolumn{3}{|l|}{ Komposisi Tepung (Terigu : Pisang : Umbi Talas) } \\
\cline { 2 - 4 } & $100 \mathrm{~g}: 200 \mathrm{~g}: 300 \mathrm{~g}$ & $200 \mathrm{~g}: 300 \mathrm{~g}: 100 \mathrm{~g}$ & $300 \mathrm{~g}: 100 \mathrm{~g}: 200 \mathrm{~g}$ \\
\hline CMC $(1,5 \%)$ & $3,4^{\mathrm{a}}$ & $3,75^{\mathrm{a}}$ & $3,7^{\mathrm{a}}$ \\
\hline Karagenan $(1,5 \%)$ & $3,65^{\mathrm{a}}$ & $3,2^{\mathrm{a}}$ & $3,28^{\mathrm{a}}$ \\
\hline
\end{tabular}

Ket : Angka yang diikuti oleh kode huruf yang berbeda menunjukkan adanya perbedaan yang nyata pada taraf signifikansi $5 \%$. Ket Skala : $1=$ sangat tidak suka; 2 = tidak suka; 3 = agak suka; $4=$ suka; $5=$ sangat suka 


\section{KESIMPULAN}

Hasil analisis kadar air pada mie basah dengan perlakuan komposisi tepung terigu, tepung pisang dan tepung umbi talas serta penambahan $\mathrm{CMC}$ dan karagenan berkisar anatar 48,89\% hingga $56,15 \%$ menunjukkan perbedaan yang nyata. Hasil analisis kadar abu pada mie basah dengan perlakuan komposisi tepung terigu, tepung pisang dan tepung umbi talas serta penambahan CMC dan karagenan berkisar antar 1,26\% hingga $3,07 \%$ menunjukkan perbedaan yang nyata. Hasil analisis elastisitas pada mie basah dengan perlakuan komposisi tepung terigu, tepung pisang dan tepung umbi talas serta penambahan CMC dan karagenan berkisar antara 2,54 hingga 3,45 menunjukka tidak beda nyata. Hasil uji organoleptik mie basah dengan perlakuan komposisi tepung terigu, tepung pisang dan tepung umbi talas serta penambahan CMC dan karagenan terhadap penilaian rasa berkisar antara 3,2 (agak suka) hingga 3,95 (suka), penilain warna berkisar antara 3,35 (agak suka) hingga 4,25 (suka), dan penilaian aroma berkisar antara 3,45 (agak suka) hingga 4,05 (suka) menunujukkan perbedaan yang nyata sedangkan uji organoleptik terhadap tekstur mie basah berkisar anatar 3,2 (agak suka) hingga 3,75 (suka) menunjukkan tidak beda nyata.

\section{DAFTAR PUSTAKA}

Antarlina, S. S. dan Utomo, J. S., 1997. Proses Pembuatan dan Penggunaan Tepung Umbi Talas Untuk Produk Pangan. Dalam Edisi Khusus Balitkabi 15-1999. Asian Journal of Food and Agro-Industry, Akses : 24 November 2011 , http://www.ajofai.info

Astawan, Made. 2008. Membuat Mie dan Bihun. Jakarta : Penebar Swadaya. Badan Pusat Statistik Indonesia.2010. Data Produksi Pisang dan Umbi Talas di Indonesia.

Bello-Perez, L.A., Y. Pano de Leon, E. AgamaAcevedo and $O$. ParedesLopez. 1999. Isolation and partial characterization of amaranth and banana starches. Starch/Starke. 50(10): 409-413.

Chandler S. 1995. The Nutritional Value of Bananas. Pp. 468-480 in Bananas and Plantains (S. Gowen, ed.). Chapman and Hall, UK.

Chang, S. M., \& Liu, L. C. (1991). Retrogradation of Rice Starches Studies by Differential Scanning Calorimetry and Influence of Sugars, $\mathrm{NaCl}$ and lipids. Journal of Food Science, 56, 564-566.

Chen, Z., Sagis, L., Legger, A., Linssen, J. P. H., Schols, H. A., \& Voragen, A. G. J. (2002). Evaluation of Starch Noodles Made from Three Typical Chinese Sweet Potato Starches. Journal of Food Science, 67(9), 3342-3347

Chen, Z., Schols, H. A., \& Voragen, A. G. J. (2003b). Starch Granule Size Strongly Determines Starch Noodle Processing and Noodle Quality. Journal of Food Science, 68(5), 1584-1589. 
Collado, Lilia.S. dan Corke, Harold. 1997. Properties of Starch Noodles as Affected by Sweetpotato Genotype. American Association of Cereal Chemists, Inc. Choo, Chong Li. 2007.

Ginting, Erliana. 2004. Pemanfaatan Pati Umbi Talas Sebagai Substitusi Terigu Pada Pembuatan Roti Manis. Balai Penelitian Tanaman Kacang-kacangan dan umbi umbian. Pustaka Sinar Harapan, Jakarta

Hartoyo, A. 1999. Kajian Teknologi Pembuatan Tepung Umbi Talas Instan Kaya Pro Vitamin A.

Maribel Ovando, Martinez; Sonia Sayago, Ayerdi; Edith Agama, Acevedo; Isabel Govil; Luis A.Bello-Perez. 2008. Unripe Banana Flour as An Ingridient to Increase The Undigestible Carbohydrates of Pasta. Food Chemistry.

MartinCaphlin,Akses : 23 Oktober 2011, http://www.lsbu.ac.uk/water/hycm c.html
Munarso, S.Joni; Haryanto, Bambang. 2008. Perkembangan Teknologi Pengolahan Mie. Panlasigui, L. N., Thomson, L. U., Jenkins, D. J. A., Juliano, B. O., Perez, C. O., \& Yiu, S. (1990).

Mushollaeni, Wahyu. 2006. Diktat Analisa Bahan Makanan

Tan, Z. Li, dan B. Tan. 2009. Starch Noodles: History, Classification, Materials, Processing, Structure, Nutrition, Quality Evaluating and Improving, Journal of Food Research International 42

Winarno, F.G. 2004. Kimia Pangan dan Gizi . PT Gramedia Pustaka Utama :Jakarta.

Winarno, F.G. dan T.S. Rahayu, 1994. Bahan Makanan Tambahan untuk Makanan dan Kontaminan. Pustaka Sinar Harapan, Jakarta

Zahro, Nurul 2013, Analisa Mutu Pangan dan Hasil Pertanian. Universitas jember 